\title{
Late Holocene climate and environment of the SE Pampa grasslands, Argentina, inferred from biological indicators in shallow, freshwater Lake Nahuel Rucá
}

\author{
Silvina Stutz • C. Marcela Borel - Sonia L. Fontana • \\ Laura del Puerto $\cdot$ Hugo Inda $\cdot$ Felipe García-Rodriguez • \\ Marcela S. Tonello
}

Received: 28 May 2009/Accepted: 16 June 2010/Published online: 30 June 2010

(C) The Author(s) 2010. This article is published with open access at Springerlink.com

\begin{abstract}
We analyzed pollen, non-pollen palynomorphs (NPPs), calcareous microfossils, plant macrofossils, diatoms, chrysophyte cysts, opal phytoliths and organic matter content in a 123 -cm sediment sequence from Nahuel Rucá Lake, a shallow, freshwater system in the southeastern Pampa grasslands, Argentina. Three stages in the lake evolution were identified. Before 3,680 cal year BP, only pollen, NPPs (dinoflagellate cysts and acritarchs) and ostracods were recovered, suggesting brackish/saline conditions in the lake and nearby areas. Freshwater conditions are, however, indicated by Myriophyllum, Pediastrum and Zygnemataceae. The brackish/saline conditions could have been caused by marine influence during a Holocene sea level high stand that
\end{abstract}

S. Stutz $(\bowtie) \cdot$ M. S. Tonello

Laboratorio de Paleoecología y Palinología, FCEyN,

Universidad Nacional de Mar del Plata, Funes 3250,

7600 Mar del Plata, Argentina

e-mail: smstutz@mdp.edu.ar

C. M. Borel

Laboratorio de Palinología, INGEOSUR-Depto. de Geología, Universidad Nacional del Sur, San Juan 670, 8000 Bahía Blanca, Argentina

e-mail:maborel@criba.edu.ar

\section{S. L. Fontana}

Department of Palynology and Climate Dynamics, University of Göttingen, Untere Karspüle 2, 37073

Göttingen, Germany

e-mail: sonia.fontana@biologie.uni-goettingen.de;

sonia.fontana@ebc.uu.se affected the area ca. 6,000 year BP. Between 3,680 and 390 cal year BP, macrophyte pollen and plant macrofossils indicate increasingly freshwater conditions in the lake and the adjacent area. Diatom and ostracod assemblages, however, suggest brackish and oligotrophic conditions, giving way to freshwater and meso-eutrophic conditions toward the end of this period. The relationship between submersed macrophytes (Myriophyllum, Potamogeton, Ceratophyllum, Chara) and planktonic algae (Chlorophyta and diatoms), suggests a shift in the lake from a clear to a turbid state. This turbid state is more evident after $390 \mathrm{cal}$ year BP. High values of Pediastrum, Scenedesmus and diatoms (Cyclotella meneghiniana, Aulacoseira granulata,

\author{
S. L. Fontana \\ Department of Evolutionary Functional Genomics, EBC, \\ Uppsala University, Norbyvägen 18D, 75236 Uppsala, \\ Sweden \\ L. del Puerto · H. Inda · F. García-Rodriguez \\ Facultad de Ciencias, Universidad de la República, \\ Montevideo, Uruguay, Iguá 4225, 11400 Montevideo, \\ Uruguay \\ e-mail: felipe.garciarodriguez@gmail.com \\ S. Stutz - C. M. Borel \\ CONICET, Buenos Aires, Argentina
}


A. muzzanensis) observed during this stage could have reduced light penetration, with consequent loss of submersed plants. Pollen and plant macrofossils in the uppermost $20 \mathrm{~cm}$ indicate a shallow, freshwater lake similar to present, though an increase in brackish/ freshwater diatoms suggests an increase in salinity, perhaps related to periodic droughts. Opal phytoliths yield a regional paleoclimatic reconstruction that agrees closely with inferences made using pollen, mammals and sediment characteristics.

Keywords Holocene - Multi-proxy analysis . Paleolimnology · Pampa grasslands ·

Shallow lake

\section{Introduction}

The Pampa grasslands cover a large area in eastcentral Argentina. Several studies have provided insights into paleoenvironmental conditions since the Last Glacial Maximum (LGM), using sedimentological and biological proxies (Prieto 1996, 2000; Tonni et al. 1999; Zárate et al. 2000; Prieto et al. 2004). Nevertheless, a detailed environmental history for the Holocene, in particular for the middle-late Holocene, has not been worked out.

Lake deposits have great potential as paleoclimate archives (Cohen 2003). Despite the large number of lakes in the Pampa grasslands, about 156,000, ranging in size from 0.05 to $>10$ ha, few paleoenvironmental studies have been carried out in the region using lake sediments, and studies that have been done usually employed only one climate proxy in the sediment record (Mancini 1994; Stutz et al. 2002, 2006; Borel et al. 2003). In only one case was a multi-proxy approach taken (Fontana 2005), though it is recommended that multiple lines of evidence be used because of the complex interactions throughout lake-drainage basin ecosystems.

One approach for generating regionally robust centennial- to millennial-scale interpretations of past climate and environment is to develop multi-proxy reconstructions for a large number of comparable sites. The first challenge is to distinguish between local versus regional patterns of change, and then translate localized responses of individual lakes to the regional scale.

Most lakes that occur in the southeastern Pampa grasslands are small and shallow, $<500$ ha in area and up to $\sim 4 \mathrm{~m}$ deep. In such small, shallow systems it is possible that only local changes may be recorded. Thus, a large number of these systems must be studied to obtain a regional picture of past climate and environmental changes.

We present results from a multi-proxy study of a shallow, freshwater lake in the southeast region of the Pampa grasslands. We analyzed pollen, non-pollen palynomorphs (NPPs), calcareous microfossils (ostracods and foraminifers), plant macrofossils, diatoms, chrysophyte cysts, opal phytoliths and organic matter content in a sediment sequence retrieved from Nahuel Rucá Lake. The core spans from the late Holocene to the present, and was studied to reconstruct the lake evolution, test whether changes in various climate proxies were synchronous, and explore if the inferred climate changes could be linked to a regional climatic signal.

Site description

Nahuel Rucá $\left(37^{\circ} 37^{\prime} \mathrm{S} ; 57^{\circ} 26^{\prime} \mathrm{W} ; 0.60 \mathrm{~m}\right.$ deep, $245 \mathrm{ha}$ ) is a shallow, freshwater lake in the southeast region of the Pampa grasslands, Buenos Aires Province, Argentina (Fig. 1). The study site, like most lakes in the region, is a deflation basin situated on the windward side of paleodunes. These basins and associated paleodunes were probably formed by prevailing westerly winds during the late Pleistocene
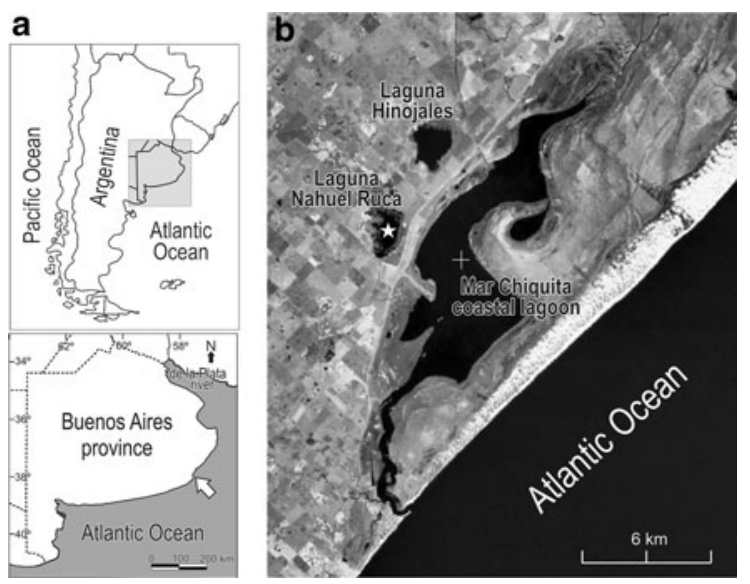

Fig. 1 a Location of study area. b General overview of the Mar Chiquita coastal lagoon area and location of Lakes Nahuel Rucá and Hinojales. Asterisk Sampling point. LNT LandSat7 (False Color). Source: World Wind $1.4 \mathrm{http}: / /$ worldwind.arc. nasa.gov/ 
(Tricart 1973). With the onset of moister Holocene conditions (Prieto 1996, 2000; Zárate et al. 2000), these depressions probably became areas of groundwater discharge and surface water accumulation, filling gradually with sediment, but subject to episodic droughts.

Nahuel Rucá Lake is associated paleoecologically with two sites, the Mar Chiquita coastal lagoon and Hinojales Lake (Fig. 1), because the entire area was affected by sea level fluctuations during the Holocene. The regional model of sea-level fluctuations, from Tierra del Fuego, Argentina to Salvador de Bahia, Brazil, proposes that after the Late Glacial Maximum, sea level rose rapidly, exceeding the modern level by 7,500-7,000 year BP. Between 6,500 and 5,500 year $\mathrm{BP}$, sea-level reached its maximum high stand, which was followed by a progressive fall before it reached its modern position (Isla 1989). For the study area in particular, Violante et al. (2001) established that sea level reached a maximum of $2.0-2.5 \mathrm{~m}$ a.s.l. between ca. 6,000 and 5,500 year BP. A Pleistocene paleocliff west of the Mar Chiquita coastal lagoon constitutes a relict of the late Pleistocene transgression and marks the limit of Holocene transgression. During the maximum sea-level stand, however, the sea surpassed this barrier in some zones and reached the shallow freshwater lakes and depressions behind it (Violante 1992; Stutz et al. 2006). During the regressive phase, an estuarine environment and a sandy barrier developed east of the Pleistocene paleocliff, and areas landward of these landforms evolved into modern shallow, freshwater lakes.

The modern regional vegetation of the study area is characterized by several genera of grasses. It lacks trees and the landscape is used intensively for agriculture and grazing. The local vegetation is characterized by sedges (Cyperus, Carex, Schoenoplectus, Eleocharis), grasses (Paspalum, Stipa, Panicum, Polypogon, Glyceria, Paspalidium), and several species of Juncus and herbaceous dicots (Eryngium, Aster, Daucus, Phyla) (Vervoorst 1967). The lake plant community is characterized by several species of emergent, floating and submersed macrophytes. The dominant species is the emergent taxon Schoenoplectus californicus which forms a complete ring around the lake. Other emergent macrophytes grow into the ring of Schoenoplectus in the shallowest zones: Zizaniopsis bonariensis, Hydrocotyle bonariensis, $H$. ranunculoides, Alternanthera philoxeroides,
Solanum glaucophyllum, Bacopa monnieri, Polygonum punctatum, Ranunculus apiifolius, Triglochin striata and Phyla canescens. Near the shore, Ricciocarpus natans (a liverwort), Azolla filiculoides (a fern), Lemna valdiviana and Wolfiella lingulata form a dense carpet. Myriophyllum elatinoides and Ceratophyllum demersum develop in the deepest parts of the lake, but are also found near shore where there is no other vegetation.

The climate of the area is temperate, with annual mean temperature and precipitation of $13.8^{\circ} \mathrm{C}$ and $941 \mathrm{~mm}$, respectively (Mar del Plata Aero meteorological station, $37^{\circ} 33.6^{\prime} \mathrm{S}, 57^{\circ} 21^{\prime} \mathrm{W}$, Servicio Meteorológico Nacional). Mean temperature varies from $20^{\circ} \mathrm{C}$ in January to $7.3^{\circ} \mathrm{C}$ in July. Rainfall occurs mainly from spring (September) to autumn (March), with a maximum of $112 \mathrm{~mm}$ in February and a minimum in August (45 mm). During summer, winds are predominantly from the N, NE and E directions, but from the NW or SW in winter.

\section{Materials and methods}

Fieldwork and sampling

A 123-cm-long core was recovered from the deepest part of the lake $(0.60 \mathrm{~m})$ with a 7 -cm-diameter vibracorer, in October 2003 (Fig. 1). In the laboratory, the core was described and sectioned at contiguous $1-\mathrm{cm}$ intervals. Subsamples were analyzed for: (1) organic matter content, (2) pollen and non-pollen palynomorphs (NPPs), (3) calcareous microfossils (ostracods and foraminifers) and plant macrofossils, and (4) diatoms, chrysophyte cysts and opal phytoliths. Samples of 1-5 g sediment were taken at $2-5 \mathrm{~cm}$ intervals for determination of organic matter content and samples of 2.5-30 g at 2-4 cm intervals for analysis of calcareous microfossils and accompanying biota. Pollen, NPPs and siliceous remains were analyzed at 1-2 cm intervals. Lithologic description was based on visual inspection (A Prieto, pers. commun.).

\section{Chronology}

Three AMS ${ }^{14} \mathrm{C}$ dates were determined on Heleobia parchapii shells and Schoenoplectus californicus achenes (Table 1). Radiocarbon ages were calibrated 
Table 1 AMS radiocarbon dates obtained from Nahuel Ruca lake

\begin{tabular}{lllrrrr}
\hline Laboratory no & Sample depth $(\mathrm{cm})$ & Dated material & $\delta^{13} \mathrm{C}$ & ${ }^{14} \mathrm{C}$ Age BP & \multicolumn{1}{l}{$\begin{array}{l}\text { cal year BP } \\
\text { (median probability) }\end{array}$} & $\begin{array}{c}2 \sigma \text { range } \\
\text { AA66206 }\end{array}$ \\
\hline AA66205 & $51-53$ & Achenes & -25.0 & $332 \pm 34$ & 388 & $297-455$ \\
Beta-193897 & $71-72$ & Achenes & -25.7 & $871 \pm 35$ & 736 & $677-793$ \\
\hline
\end{tabular}

All radiocarbon dates were calibrated with Calib 5.0.1 (Stuiver et al. 2005) using the Southern Hemisphere curve (McCormac et al. 2004)

against the Southern Hemisphere curve (SHCal04) (McCormac et al. 2004) using the program CALIB 5.0.1 (Stuiver et al. 2005). In view of the fact that there are few dates, core stratigraphy and biological proxy diagrams were plotted against depth and calibrated ages are indicated to the left of each diagram.

\section{Laboratory methods}

Organic matter content was estimated by weight losson-ignition (LOI) at $550^{\circ} \mathrm{C}$ for two hours and is expressed as a percent of dry weight (Heiri et al. 2001).

Samples for pollen and non-pollen palynomorph analysis were prepared following standard techniques, using warm $\mathrm{KOH}$, warm $\mathrm{Na}_{4} \mathrm{P}_{2} \mathrm{O}_{7}, \mathrm{HCl}$, heavy-liquid separation with $\mathrm{ZnCl}_{2}$, $\mathrm{HF}$ and acetolysis (Faegri and Iversen 1992). Two Lycopodium clavatum tablets were added before treatment. At least 300 pollen grains, including terrestrial and aquatic vascular taxa, were counted for most samples, except samples from 92, 93 and $94 \mathrm{~cm}$ depth, in which pollen concentrations were extremely low. Each pollen type was calculated as a percent of the total pollen sum (terrestrial and aquatics). NPPs were calculated as a percent of the pollen sum plus NPP sum. Percentages of Azolla filiculoides, Ricciocarpus natans and Bryophyta were calculated as percentages of the pollen sum plus spores sum. Identifications of pollen grains, spores and NPPs were made using atlases and published keys (Markgraf and D'Antoni 1978; Borel et al. 2003; Borel 2007) and the reference collections of the Laboratory of Paleoecology and Palynology, UNMdP, and Laboratory of Palynology, UNS. Pollen zones were defined using CONNISS (Grimm 1987) on pollen types with $\geq 2 \%$ of the total in at least one sample.

Calcareous microfossils (ostracods and foraminifers), plant macrofossil remains and accompanying biota were first sieved through 180- and 63- $\mu \mathrm{m}$ mesh without chemical treatment. Charophyte oospores, seeds, megaspores and Cladocera ephippia were recovered from the $180-\mu \mathrm{m}$ sieve. Material retained on the sieves was treated with hot dilute hydrogen peroxide, sieved through 250-, 125- and 63- $\mu \mathrm{m}$ mesh and dried. Ostracods, foraminifers and charophyte gyrogonites were recovered from these fractions. Ostracod nomenclature follows Martens and Behen (1994) and Whatley et al. (1997). Zones were defined numerically using optimal splitting techniques (Bennett 1996). Vascular plant nomenclature follows the catalogue of the Argentine flora published online by the Darwinion Institute (1997-2008) (http://www.darwin.edu.ar/Pro yectos/FloraArgentina/FA.asp).

Samples for diatoms, chrysophyte cysts and opal phytolith analyses were treated with $35 \% \mathrm{HCl}$ for $24 \mathrm{~h}$ to remove carbonates, and rinsed four times with distilled water. To eliminate organic matter, $10 \mathrm{ml}$ of $30 \% \mathrm{H}_{2} \mathrm{O}_{2}$ were added, and samples were boiled for $4 \mathrm{~h}$ and rinsed five times with distilled water. Permanent slides were mounted in Naphrax ${ }^{\circledR}$ for counting and identification. At least 300 diatoms, and usually $>350$, were counted. Chrysophyte cysts were counted along with diatoms and expressed as a percent of their abundance relative to the total number of diatom valves and chrysophyte cysts (Karst and Smol 2000). Diatoms were identified according to Frenguelli (1941, 1945) and Metzeltin et al. (2005). Information on the environmental requirements and habitats of diatoms was taken from Frenguelli (1941, 1945), Metzeltin et al. (2005) and Hassan et al. (2006). Diatom zones were defined using complete linkage Stratigraphically Constrained Cluster Analysis using the program PAST 1.81 (Hammer et al. 2008). The Morisita Index was used to assess the strength of the association among diatom assemblages.

A minimum of 200 phytoliths was counted at $1,000 \times$ magnification in each sample. Phytoliths were 
identified according to Bozarth (1992), Twiss (1992), Fredlund and Tieszen (1994), del Puerto (2009), and using the reference collection of the Faculty of Sciences, UdR. Although phytoliths cannot be assigned to individual grass taxa, ratios of phytolith types (pooid, chloridoid and panicoid) can be used as climate indicators.

Taxonomic problems in grass phytolith classification derived from multiplicity, i.e., the same plant produces different phytolith forms, and redundancy, i.e., the same phytolith form is produced by different plant taxa (Rovner 1992). Nevertheless, when phytolith investigations are not used solely to identify grass taxa, but rather to assess the relationship between phytolith assemblages and grassland composition, the morphotype classification system is both taxonomically and environmentally sensitive (Fredlund and Tieszen 1994). del Puerto et al. (2006) address other problems with respect to taxonomic identification of opal phytoliths in the South American Pampa grasslands. Because the grasses of southern Uruguay and eastern Argentina are similar, the reference collection of phytoliths of del Puerto et al. (2006) can be used for phytolith identification in the area of Nahuel Rucá Lake. Despite such problems as multiplicity and redundancy, the Twiss classification of grass phytoliths was shown to be a reliable tool for inferring paleoclimate changes and has been tested using multi-proxy approaches (Fredlund and Tieszen 1997; Alexandre et al. 1999; Baker et al. 2000; Bracco et al. 2005b).

Where $\mathrm{C}_{3}$-type grasses occur, the ratio of $\mathrm{C}_{3}$ to $\mathrm{C}_{4}$ phytoliths can be used as an index of temperature (Twiss 1992) following the equation:

\section{Temperature index}

$$
=\frac{\text { Pooid }}{\text { Pooid }+ \text { Panicoid }+ \text { Chloridoid }} \times 100
$$

High index values suggest a cool climate, comparable to high latitudes or altitudes where $\mathrm{C}_{3}$ grasses are prevalent, and low index values suggest warm temperatures, characteristic of low latitudes or elevations. Opal phytolith analyses carried out on surface sediment samples from cattle/sheep enclosures, with the aim of obtaining a record of present climate conditions, yielded Temperature Index (TI) values between 48 in NW Uruguay and 60 in SE Buenos Aires Province, Argentina (del Puerto 2009).
Similarly, by comparing chloridoid to the sum of chloridoid and panicoid phytoliths it is possible to obtain a humidity index:

Humidity index $=\frac{\text { Chloridoid }}{\text { Chloridoid }+ \text { Panicoid }} \times 100$

High index values indicate an arid climate, while low values indicate a humid climate. Opal phytoliths in surface deposits of cattle/sheep enclosures registered Humidity Index (HI) values between 10 in southern Uruguay and 16 (SE Buenos Aires Province) for Pampa grasslands (del Puerto 2009).

Opal phytolith zones were defined using complete linkage Stratigraphically Constrained Cluster Analysis using the program PAST 1.81 (Hammer et al. 2008). The Morisita Index was used to assess the strength of the association among phytolith assemblages.

The LOI, pollen and NPPs, diatom and phytolith diagrams were created using TGView 2.0.2 (Grimm 2004), while Psimpoll 4.26 software (Bennett 2008) was used for the diagram of calcareous microfossils and accompanying biota.

\section{Results}

Lithology and LOI

The sediment core was divided into seven lithologic sections (Figs. 2, 3, 4, 5). The lowermost sediments consist of silty sand with calcrete concretions (123$118 \mathrm{~cm})$ overlain by clay-rich sediments $(118-86 \mathrm{~cm})$. Samples from these two sections were sterile or yielded only low amounts of plant or animal remains. LOI values were $<10 \%$ in these lower sediment units (Fig. 2). Organic matter content increased between 75 and $62 \mathrm{~cm}$, reaching values up to $40 \%$. Above $62 \mathrm{~cm}$, LOI values decreased, first sharply and then more gradually to $5 \%$ at $40 \mathrm{~cm}$, and then rose towards the top, where LOI values reached $35 \%$.

Pollen and NPPs were analyzed from $94 \mathrm{~cm}$ to the top (Fig. 2). Four Pollen Association Zones (PAZ) were distinguished.

PAZ1 $(94-88 \mathrm{~cm})$ is characterized by maximum values of Chenopodiaceae, accompanied by Cyperaceae and Poaceae. Asteroideae, Ambrosia, Myriophyllum and other herbs occur in low percentages. Among NPPs, the spectra are characterized by Pediastrum and maximum values of Zygnemataceae zygospores, 
Nahuel Rucá lake ( $\left.37^{\circ} 37^{\prime} \mathrm{S}, 57^{\circ} 26^{\prime} \mathrm{W}\right)$

Analysts: Marcela Borel and Silvina Stutz

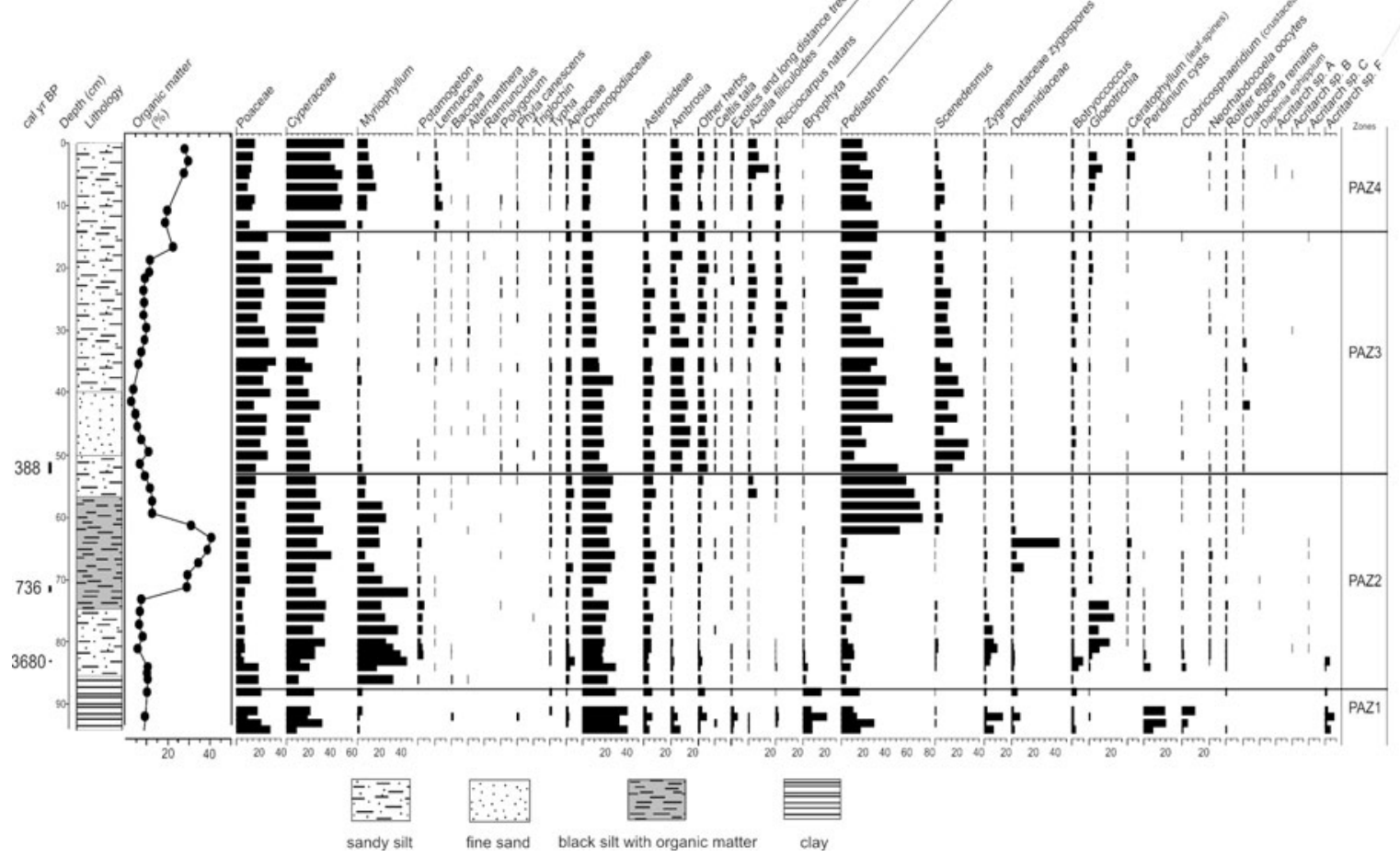

Fig. 2 Pollen and non-pollen palynomorph percentages and organic matter content (\%) from Nahuel Rucá Lake, including chronology and lithology. Zones were defined using CONISS

Peridinium cysts, Cobricosphaeridium, and Acritarch sp. F.

PAZ2 $(88-53 \mathrm{~cm})$ is characterized by maximum values of Myriophyllum, increasing values of Cyperaceae and decreasing values of Poaceae and Chenopodiaceae. Potamogeton reaches highest values in the sequence. Low quantities of Asteroideae $(\leq 15 \%)$, Apiaceae and Ambrosia $(\leq 10 \%)$ are registered. Pediastrum exhibits maximum values $(>60 \%)$, also Desmidiaceae (up to $45 \%$ ), Gloeotrichia (up to $25 \%$ ) and Botryococcus (up to 10\%). Peridinium cysts and Cobricosphaeridium register decreasing values. Ceratophyllum is present, with values up to $10 \%$.

PAZ3 $(53-15 \mathrm{~cm})$ is characterized by Cyperaceae and Poaceae, with maximum values of up to $35 \%$, accompanied by Chenopodiaceae, Ambrosia, Asteroideae and Apiaceae. Pollen percentage values of the macrophytes Lemnaceae, Bacopa, Alternanthera, Ranunculus, Phyla and Triglochin are low, but constant in this zone. Values of Azolla filiculoides and Ricciocarpus natans increase to the top of the zone. With respect to NPPs, the zone is characterized by Pediastrum and maximum values of Scenedesmus, up to $35 \%$.

PAZ4 $(15-0 \mathrm{~cm})$ is characterized by maximum values of Cyperaceae and Lemnaceae, accompanied by Poaceae, increasing values of Myriophyllum and Chenopodiaceae and Ambrosia. In addition, Azolla filiculoides reaches maximum values. The NPP proportions of Gloeotrichia and Ceratophyllum increase, while Pediastrum and Scenedesmus abundances decrease.

The calcareous microfossils (ostracods and foraminifers), charophytes and plant macrofossils recovered are summarized in Fig. 3. A few specimens of Limnocythere cf. staplini were encountered at the base of the sequence, below $88 \mathrm{~cm}$, but were not considered in zonation of the diagram. The sequence was divided into four Calcareous Microfossil Association Zones (CMZ).

CMZ1 $(88-72 \mathrm{~cm})$ contains the highest concentration and diversity of fossils. The zone is mainly dominated by oospores and gyrogonites of Chara, which reach their maximum values in the sequence. 


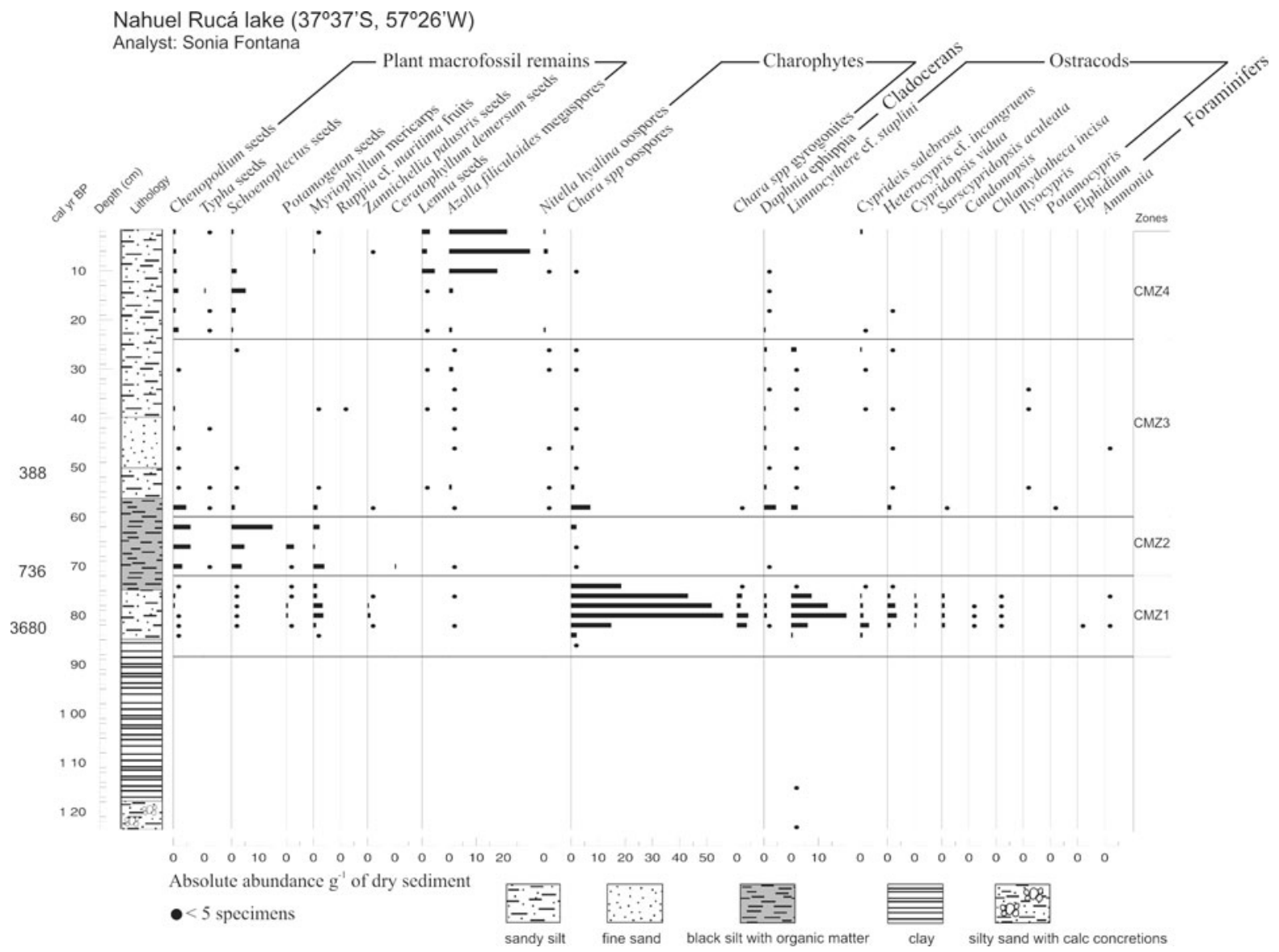

Fig. 3 Abundance of calcareous microfossils (ostracods and foraminifera) and macro remains from Nahuel Rucá Lake, including chronology and lithology. Zones were defined using optimal splitting by information content after applying squareroot transformation to the dataset

and Heterocypris cf. incongruens are the most frequent remains within this zone.

CMA4 $(24-0 \mathrm{~cm})$ is dominated by plant macrofossils, Azolla filiculoides megaspores and minor quantities of Lemna and Chenopodium seeds.

Seventy-four diatom species were identified throughout the sediment core. No valves were preserved below $82 \mathrm{~cm}$. The most abundant species ( $>2 \%$ in at least three samples) are shown in Fig. 4. Four Diatom Association Zones (DAZ), were identified.

DAZ1 $(82-69 \mathrm{~cm})$ is dominated by Aulacoseira granulata var. angustissima and A. granulata. Co-dominant species include Campylodiscus clypeus, Cyclotella meneghiniana, Epithemia adnata, Surirella striatula, Caloneis formosa, and Hyalodiscus subtilis. The basal sample of this DAZ exhibits a high ratio of 


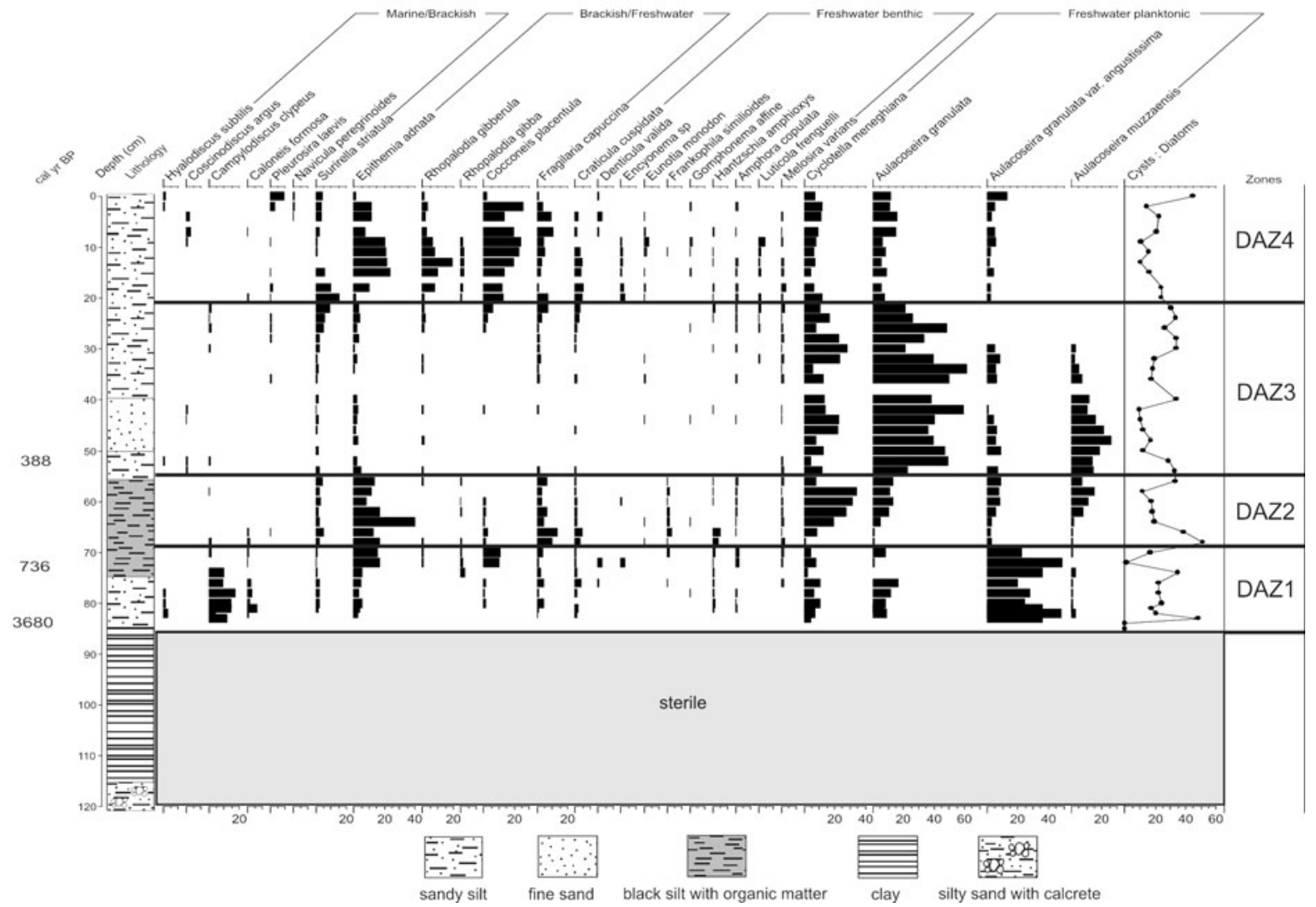

Fig. 4 Diatom percentages from Nahuel Rucá Lake, including chronology and lithology. Zones were defined using cluster analysis. The Morisita Index was used to assess the strength of the association among diatom assemblages

cysts to diatoms, which decreases upwards. In the upper section, a sharp increase in abundance values of A. granulata var. angustissima is observed, together with a sharp decrease in cyst/diatom ratio.

DAZ2 $(69-55 \mathrm{~cm})$ is dominated by Cyclotella meneghiniana and Epithemia adnata (45\%). Co-dominant species are Aulacoseira muzzanensis, A. granulata and Fragilaria capuccina. A decrease in cyst/ diatom ratio is recorded. However, towards the upper section of this DAZ, cyst/diatom ratio increased.

DAZ3 $(55-21 \mathrm{~cm})$ is characterized by a sharp increase in the relative abundance of Aulacoseira granulata, accompanied by A. granulata var. angustissima, A. muzzanensis and Cyclotella meneghiniana. The cyst/diatom ratio decreased.

DAZ4 $(20-0 \mathrm{~cm})$ exhibits the highest relative abundances of Epithemia adnata, Cocconeis placentula, Rhopalodia gibberula, together with Aulacoseira granulata and Cyclotella meneghiniana. The cyst/ diatom ratio continues to decrease within DAZ 4, except for the surface sediment sample, in which the cyst/diatom ratio increases.

Opal phytoliths were found only in the upper $104 \mathrm{~cm}$ of the sediment core (Fig. 5). Below $83 \mathrm{~cm}$ depth, phytoliths were scarce and showed signs of corrosion and fragmentation. Eight Opal Phytolith Association Zones (OPAZ) were identified.

OPAZ1 $(104-83 \mathrm{~cm})$ is characterized by dominance of grass phytoliths, mainly short cells of $\mathrm{C} 3$ species from the Pooidae subfamily (particularly Avenae and Poeae tribes), although arundinoid morphotypes were also observed. There was low abundance of C4 cells, with more panicoid (Paniceae and Andropogoneae tribes) than chloridoid phytoliths. Temperature index values indicate conditions colder than present and humidity index values display high 


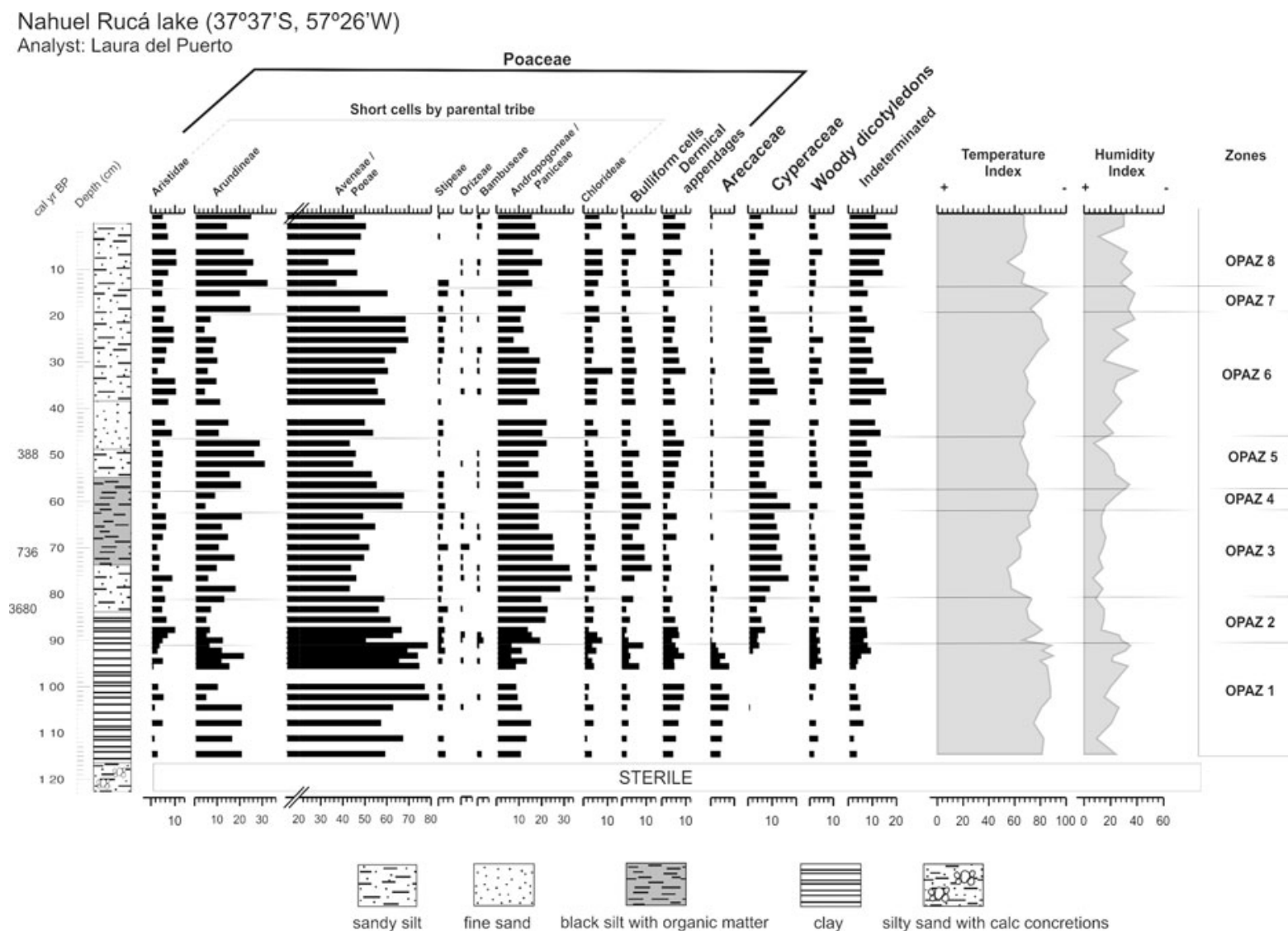

Fig. 5 Phytolith percentages from Nahuel Rucá Lake, including chronology and lithology. Zones were defined using cluster analysis. The Morisita Index was used to assess the strength of the association among phytolith assemblages

variability. In addition to grass phytoliths, globular echinate phytoliths, produced by Arecaceae (palms), were found in OPAZ1. In the upper section of this zone, Cyperaceae phytoliths and abundant phytoliths from woody dicots (probably shrubs) were identified.

OPAZ2 $(82-74 \mathrm{~cm})$ is characterized by a sharp decrease in pooid and arundonoid phytoliths and an increase in panicoid and aristidoid phytoliths. Cyperaceae are also abundant in this zone. Temperature and humidity indices suggest increases in both temperature and humidity towards the top of this zone.

OPAZ3 $(72-58 \mathrm{~cm})$ displays an intensification of the trend observed in the former section and maximum values of panicoid and minima of pooid phytoliths yielded minimum values of both temperature and humidity indices. Maximum abundances of Cyperaceae are also registered in this zone.

OPAZ4 $(56-54 \mathrm{~cm})$ represents a further increase in pooid phytoliths and a decrease in panicoid phytoliths.
High abundance of sedges and low numbers of woody dicot phytoliths also characterize this zone.

OPAZ5 $(52-44 \mathrm{~cm})$ is defined by a decrease in both pooid and chloridoid phytoliths and by an increase in panicoid and arundinoid phytoliths. This implies a decrease in both temperature and humidity indices. Low abundances of sedges and woody elements are also observed.

OPAZ6 $(42-20 \mathrm{~cm})$ is marked by decreases in panicoid and arundinoid phytoliths, together with an increase in pooid phytoliths. There is also an increase in abundance of aristidoid phytoliths, while chloridoid types vary. Toward the top of this zone, there is an increasing trend in the temperature index, while the humidity index shows high variability. Cyperaceae and woody dicots also increase.

OPAZ7 $(18-15 \mathrm{~cm})$ is characterized by an increase in arundinoid phytoliths, together with a decrease in both pooid and panicoid cells. There is also a decrease in sedges and woody dicots. Humidity and temperature 
indices show similar values to those at the top of the underlying OPAZ.

OPAZ8 $(13-0 \mathrm{~cm})$ is characterized by pooid dominance, followed by rundinoid and panicoid phytoliths. Chloridoid and aristidoid phytoliths show similar values, and other groups of grass cells display lower values. In addition to grass cells, sedges show values similar to those of aristidoid phytoliths, while trees and shrubs exhibit lower values. Temperature and humidity indices show decreasing values compared to the former zone.

\section{Discussion}

There are potential problems with the chronology of the Nahuel Rucá core. The first issue is potential hardwater-lake effect that could cause radiocarbon dates on shells to be too old. A study in a similar ecosystem of the southwestern Pampa grasslands, however, demonstrated there was no effect on dated Heleobia parchapii shells (Fontana 2007). Ideally, such an evaluation should be done on each system studied. Nevertheless, we accepted the radiocarbon age of 3,680 year cal BP $\left(3,480 \pm 40{ }^{14} \mathrm{C}\right)$. If all radiocarbon dates are correct, the uppermost $72 \mathrm{~cm}$ of the core represent $\sim 740 \mathrm{cal}$ year of accumulation. The underlying $10-11 \mathrm{~cm}$ are separated by 2,940 cal year (i.e., dates of 740 and $3,680 \mathrm{cal}$ year), and the bottommost $40 \mathrm{~cm}$ are older than 3,680 cal year. We have no simple explanation for the long period of time, $\sim 2,900$ years, represented by the interval between 83 and $72 \mathrm{~cm}$. The core displays a lithologic change at $75 \mathrm{~cm}$, with an increase in organic matter content. One possible explanation for the apparent slow sedimentation rate is an unconformity due to an erosional event in the past, followed by the onset of sedimentation of a different type of material. A similar process may have also occurred in other ecosystems in the region, e.g., Lakes Tobares and Lonkoy (Stutz unpublished data). Despite a paucity of radiocarbon dates it is possible to suggest a tentative chronology for the stratigraphic shifts in paleoenvironmental indicators, which allows a comparison with other late Holocene records from the region.

Lake evolution

Simultaneous changes in pollen, NPPs, diatoms, opal phytoliths, ostracods and plant macrofossils, reveal five main stages in the lake evolution. Prior to 3,680 cal year BP, phytoliths, pollen and NPPs and ostracods valves were recovered, although in low concentration. Pollen spectra, dominated by Chenopodiaceae, suggest a halophytic plant community grew in the surrounding area. Among the NPPs, Pediastrum, Botryococcus and Zygnemataceae zygospores, together with submersed Myriophyllum, indicate a freshwater lake. On the other hand, brackish to saline conditions can be inferred from Cobricosphaeridium (copepod or anostracod eggs; Head et al. 2003), Peridinium cysts and Acritarch sp. F (possible cysts of prasinophycean algae; Borel 2007), as well as the presence of the ostracod Limnocythere cf. staplini. The brackish/saline conditions in Nahuel Rucá Lake could have been the result of the intrusion of seawater into the former freshwater lake during the maximum Holocene sea level stand, as occurred in contiguous shallow Lake Hinojales, where ca. 4,710 cal year BP, pollen spectra indicate a halophytic plant community, and diatom, ostracod, microforam, mollusk and NPP assemblages indicate a brackish/saline influence in the fresh water body (Stutz et al. 2002, 2006; Borel et al. 2003). This NPP assemblage, associated with Ruppia, was also registered in some southwestern Pampa grassland creeks, Claromecó, Las Brusquitas and La Ballenera (Stutz et al. 1999; Vilanova et al. 2006; Borel 2007), indicating brackish conditions in the water bodies and marsh environments that developed by ca. 6,2005,500 cal year BP during the Holocene sea level high stand. In Negra lagoon, southeastern Uruguay, the same NPPs and pollen spectra are recorded during the period when the lagoon was open to the sea (GarciaRodriguez et al. 2010). Between 3,680 and 740 cal year BP, freshwater conditions apparently dominated Nahuel Rucá. According to Scheffer (1998), maximum values of both pollen and plant macrofossils of the submersed macrophytes Myriophyllum, Potamogeton, Ceratophyllum and Chara suggest a clear water body with considerable light penetration. This interpretation is supported by low abundances of planktonic algae, including Pediastrum, Scenedesmus and Botryococcus, although Aulacoseira granulate, var. angustissima, a freshwater planktonic diatom, displays highest values, up to $50 \%$. Scheffer's concept postulates that shallow lakes may possess two alternative states: a clear-water phase, with high water transparency, low phytoplankton biomass and predominance of macrophytes, and a turbid state, with low 
transparency, high phytoplankton biomass and low abundance of macrophytes (Scheffer and Jeppesen 2007). Paleolimnological data have been used to track alternative states of shallow lakes (Karst and Smol 2000; García-Rodríguez et al. 2004). Even though sea level was beginning to decrease toward its present position, and pollen and NPP spectra show decreasing values of Chenopodiaceae and Peridinium cysts, ostracod and diatom spectra still show elements that suggest brackish conditions in the water body. DAZ1 exhibits the highest values of Campylodiscus clypeus and other less abundant marine/brackish species such as Surirella striatula and Caloneis formosa. The components of the ostracod assemblage, Limnocythere cf. staplini, Cyprideis salebrosa, Heterocypris cf. incongruens and Sarscypridopsis aculeata, are characteristic of brackish, shallow-water environments, and indicate an oligotrophic, alkaline water body, with low phosphorus content and ph above 6 . The dominance of Limnocythere cf. staplini could also indicate high-salinity conditions. The presence of foraminifers suggests close proximity to the sea. Among the opal phytoliths, those of Cyperaceae begin to increase around this time, indicating the re-establishment of freshwater conditions. Nutrient-limited growth conditions, together with good light availability, may explain the higher frequencies of Gloeotrichia (PAZ2). The cyanobacteria have a competitive advantage over other taxa by virtue of their $\mathrm{N}_{2}$-fixing capability, but nitrogen fixation demands a large amount of energy and consequently requires high light availability in relatively shallow water (van Geel et al. 1996). Between 740 and 390 cal year BP, pollen of Myriophyllum and Potamogeton decrease slightly, though macrofossils (mericarps and seeds) of these submersed macrophytes remain almost constant (CMZ2). At the top of PAZ2, planktonic algae Pediastrum and Desmidiaceae reach highest values and Scenedesmus increases, indicating a shift to a turbid state. The diatom spectra also show increasing values for freshwater planktonic species (e.g., Cyclotella meneghiniana). Increased planktonic microalgae populations could have reduced light penetration, with the consequent loss of Chara beds on the lake floor. Myriophyllum and Potamogeton can tolerate much more turbidity than charophytes (Blindow et al. 2002). This shift from a clear to a turbid state is also reflected in the changing ratio between cysts and diatoms, which indicates trophic state variability. According to García-
Rodríguez (2006) trophic state is higher when cyst/ diatom ratios are lower. Ostracod assemblages (CMZ2) also indicate trophic state variability, with mesotrophic to eutrophic conditions (high phosphorus and nitrate content, and $\mathrm{ph} \geq 7$ ). Maximum values of shoreline and emergent macrophyte remains, specifically Schoenoplectus and Chenopodium seeds, indicate near-shore conditions and thus low lake levels. Maximum values of organic matter content (up to $40 \%$ ) were observed during this episode. Opal phytoliths of Cyperaceae display maximum values. After 390 cal year BP, freshwater meso-eutrophic planktonic species accounted for approximately $90 \%$ of the relative abundance, suggesting an increase in trophic state. This is also supported by the decrease in cyst/ diatom ratios, as observed in DAZ2. Maximum values of Aulacoseira granulata occur coincident with maximum values for the planktonic chlorophycean Pediastrum and for Scenedesmus, and minimum values for Myriophyllum. This suggests that the lake was turbid during this period. Increasing values for floating Azolla filiculoides (micro and macro spores) and Ricciocarpus natans, which form a dense cover on the surface of the modern lake, could have also contributed to reduced light penetration. The increase in pollen percentages of emergent macrophytes, Bacopa, Alternanthera, Ranunculus, Polygonum, Phyla canescens and Triglochin indicate conditions similar to those in the modern lake. Low numbers of calcareous microfossils and plant remains in this section, together with a high abundance of gastropod shell fragments, suggests sediments were deposited under high-energy conditions. The top $20 \mathrm{~cm}$ of the core are interpreted to represent modern lake conditions. The pollen spectra reflect the modern plant community, dominated by Schoenoplectus (Cyperaceae) accompanied by Myriophyllum and a dense carpet of Lemnaceae (Lemna, Wolfiellla), Azolla filiculoides and Ricciocarpus natans. Although plant macrofossils, pollen and NPP spectra indicate freshwater conditions, the increase in brackish/freshwater diatom species, together with a decrease in freshwater taxa, suggests that the system might have increased in salinity. This is also supported by the decrease in cyst/diatom ratios (García-Rodríguez 2006). Pulses of increased brackish conditions could be the consequence of episodic droughts that have affected this part of the Pampa grasslands over last 150 years (Deschamps et al. 2003). The dense carpet of free-floating species could have reduced light 
penetration and dissolved oxygen concentration in the water column, causing the loss of submersed aquatic plants by shading and subsequent anoxia. Increases in pollen of Myriophyllum and leaf-spines of Ceratophyllum, accompanied by a slight decrease in planktonic algae, chlorophytes, and diatoms, suggests re-colonization by these plants, with a consequent change in light penetration. Furthermore, the increase of Gloeotrichia in this zone may reflect greater energy available for nitrogen fixation by these cyanobacteria, as a result of higher light intensity.

\section{Paleoclimate trends}

The proxies analyzed in the Nahuel Rucá Lake core reflect primarily changes in lake evolution. To infer past climate changes it is necessary to translate local responses from several sites to the regional scale. Analysis of opal phytoliths was used to calculate temperature and humidity indices, which can be used to infer paleoclimate changes. The paleoclimate interpretations are based on phytoliths and are compared with information provided by others lines of evidence, i.e., pollen, faunal assemblages, and sedimentology from aquatic ecosystems and archaeological sites of the Pampa grasslands. High values of temperature and humidity indices indicate conditions cooler than today with episodes of aridity or seasonal rainfall during the transition from the middle to the late Holocene, before ca. 3,700 cal year BP. This is in agreement with the model based on sedimentological records (Iriondo and Garcia 1993), that suggests a change from warm and perhaps more humid conditions to a semi-arid phase at the beginning of the late Holocene. Despite the fact that paleoclimate data for the late Holocene in the Pampa grasslands are fragmentary, and in some cases controversial, many authors agree that after ca. 5,000 year BP, climate became drier, with short episodes of semiarid or humid and warm conditions (Zárate et al. 2000; Prieto et al. 2004; Mancini et al. 2005; Quattrocchio et al. 2008). The development of characteristic dry pampa grasslands suggests regional sub-humid to dry conditions (Prieto 1996), while faunal assemblages suggest semi-arid conditions with temperatures slightly higher than modern ones (Tonni et al. 1999). In the SE Pampa grasslands, a temperate climate at ca. 3,000 cal year BP, with probable further increases in dryness and seasonality during the late
Holocene, is inferred from diatoms (Bonomo et al. 2009). Declines in the temperature and humidity indices suggest climatic conditions warmer and more humid at the beginning of the late Holocene, after 3,700 cal year BP, than in the previous period. The maximum values attained by ca. $740 \mathrm{cal}$ year BP indicate an episode of cooler and drier conditions. The change to warmer and wetter conditions similar to present times was also inferred from opal phytolith records from southeastern Uruguay (Castillos and Negra Lakes) after ca. 2,000 cal year BP. At Negra Lake, these conditions were followed by a dry and cold event (Bracco et al. 2005a, b; del Puerto 2009). Mammal assemblages from the southern Pampa grasslands suggest a transition from humid to arid conditions between 2,000 and $500{ }^{14} \mathrm{C}$ year BP (Tonni et al. 1999; Prado and Alberdi 1999). Quantitative precipitation reconstructions based on pollen sequences showed precipitation values $100 \mathrm{~mm}$ greater than modern values between 2,000 and 500 cal year BP, suggesting sub-humid to dry conditions for the southwest Pampa grasslands, while sub-humid to humid conditions similar to modern were inferred for the central area (Tonello and Prieto 2010). These precipitation reconstructions coincide with the positive humidity index values based on phytoliths at Nahuel Rucá Lake. Therefore, warm and humid conditions would have represented a mosaic of microhabitats.

During the last $400 \mathrm{cal}$ year, the temperature and humidity indices indicate a decrease in temperature and a highly variable hydrologic regime. These conditions are also registered by faunal assemblages from the Pampa grasslands (Tonni et al. 1999) and by paleolimnological records from southern Uruguay (Bracco et al. 2005b), and have been associated with the Little Ice Age, which is generally thought to have occurred between 400 and 150 cal year BP (Bradley et al. 2003; Villalba et al. 2005). At Nahuel Rucá Lake, however, cold and fluctuating humid-dry conditions persisted until the present. Inferred precipitation values decrease during the last $500 \mathrm{cal}$ year in the southwest Pampa grasslands, suggesting semiarid climate conditions (Tonello and Prieto, 2010). Historic chronicles and geomorphologic data indicate arid conditions in post-Hispanic times, with intervals of increased precipitation (Tonni et al. 1999; Deschamps and Tonni 2007). Short-term fluctuations in climate during this last interval may have been sufficient to initiate changes in the water bodies, with 
a general reduction in the lake volume, but intermittent periods of flooding.

\section{Conclusions}

The evolution of shallow Nahuel Rucá Lake during the late Holocene was reconstructed using seven sources of paleoecological information: pollen, NPPs, calcareous macrofossils (ostracods and foraminifers), plant macrofossils, diatoms, opal phytoliths and organic matter. There was a close correspondence in the timing of assemblage changes for all biological proxies in the core. These proxies explain the history of the lake evolution. Paleoclimate was inferred from opal phytoliths and results are in agreement with other Holocene paleoclimate reconstructions from the region that utilized pollen, faunal assemblages, and sedimentology as proxies. Prior to 3,680 cal year BP, a shallow, freshwater lake with marine influence developed. After the onset of full freshwater conditions, two stages can be recognized in the evolution of the lake: (1) between 3,680 and 740 cal year BP, a clear state, dominated by macrophytes, and (2) a subsequent turbid state dominated by planktonic algae.

This study sheds light on the Holocene sea level history of the region, and established that sea level reached areas beyond the Pleistocene paleocliff, as in shallow Hinojales Lake (Stutz et al. 2002, 2006). The multi-proxy approach we used here must be extended to other shallow lakes in the area to obtain data for regional paleoclimate and paleoenvironment models.

Acknowledgments We thank P. Urrutia for giving us permission to work on his property, and A. González, M. Hernandez, I. Vilanova for their support during coring activities. F. I. Isla kindly lent us the vibracorer and $\mathrm{T}$. Giesecke provided valuable comments on an early version of the manuscript. We thank the (NSF)-Arizona AMS Facility and T. Jull for financial support for dating. We thank Mark Brenner and two anonymous reviewers for helpful comments. Mark Brenner kindly corrected the English. Financial support was provided by PICT No. 32345 (ANPCyT) and EXA 384/07 (UNMdP).

Open Access This article is distributed under the terms of the Creative Commons Attribution Noncommercial License which permits any noncommercial use, distribution, and reproduction in any medium, provided the original author(s) and source are credited.

\section{References}

Alexandre A, Meunier JD, Mariotti A, Soubies F (1999) Late Holocene phytolith and carbon-isotope record from a Latosol at Salitre, South-Central Brazil. Quat Res 51: 187-194

Baker RG, Fredlund GG, Mandel RD, Bettis EA (2000) Holocene environments of the central Great Plains: multiproxy evidence from alluvial sequences, southeastern Nebraska. Quat Int 67:75-88

Bennett KD (1996) Determination of the number of zones in a biostratigraphical sequence. New Phytol 132:155-170

Bennett KD (2008) Psimpoll 4.26: C program for plotting pollen diagrams and analyzing pollen data. Available online from Queen's University of Belfast, Department of Archaeology and Palaeoecology. http://www.chrono.qub. ac.uk/psimpoll/psimpoll.html. Last Accessed 12 May 2008

Blindow I, Hargeby A, Andersson G (2002) Seasonal changes of mechanisms maintaining clear water in a shallow lake with abundant Chara vegetation. Aquat Bot 72:315-334

Bonomo M, Zucol AF, Gutiérrez Tellez B, Coradeghini A, Vigna MS (2009) Late Holocene palaeoenvironments of the Nutria Mansa 1 archaeological site, Argentina. J Paleolimnol 41:273-296

Borel CM (2007) Algas no silíceas y acritarcos de depósitos costeros holocenos en el arroyo La Ballenera, provincia de Buenos Aires, Argentina. Ameghiniana 44:359-366

Borel CM, Guerstein GR, Prieto AR (2003) Palinomorfos acuáticos (algas y acritarcos) del Holoceno de la laguna Hinojales (Buenos Aires, Argentina): interpretación paleoecológica. Ameghiniana 40:531-544

Bozarth S (1992) Classification of opal phytoliths formed in selected dicotyledons native to the Great Plains. In: Rapp G, Mulholland H (eds) Phytolith systematics. Plenum Press, New York, pp 193-214

Bracco R, del Puerto L, Inda H, Castiñeira C (2005a) Mid-to late Holocene cultural and environmental dynamics in eastern Uruguay. Quat Int 132:37-45

Bracco R, Inda H, del Puerto L, Castiñeira C, Sprechmann P, García-Rodríguez F (2005b) Relationships between Holocene sea-level variation, trophic development and climate change in Negra Lagoon, southern Uruguay. J Paleolimnol 33:252-262

Bradley RS, Briffa KR, Cole J, Hughes MK, Osborn TJ (2003) The climate of the last millennium. In: Alverson KD, Bradley RS, Pederson TF (eds) Paleoclimate, global change and the future. Springer, New York, pp 105-141

Cohen AS (2003) Paleolimnology: the history and evolution of lake systems. Oxford University Press, $500 \mathrm{pp}$

del Puerto L (2009) Silicofitolitos como Indicadores Paleoambientales: bases comparativas y reconstrucción paleoclimática a partir del Pleistoceno Tardío en el SE del Uruguay. Mg Thesis PEDECIBA, Facultad de Ciencias, Universidad de la República, Montevideo, 189 pp (unpublished)

del Puerto L, García-Rodríguez F, Inda H, Bracco R, Castiñeira C, Adams JB (2006) Paleolimnological evidence of Holocene climatic changes in Lake Blanca, southern Uruguay. J Paleolimnol 36:151-163 
Deschamps JR, Tonni EP (2007) Aspectos ambientales en torno al primer fuerte de la frontera sur de Buenos Aires: "El Zanjón” 1745-1779. de Trabajo no. 175. Departamento de Investigaciones, Universidad de Belgrano, $24 \mathrm{pp}$

Deschamps JR, Otero O, Tonni EP (2003) Cambio climático en la pampa bonaerense: las precipitaciones desde los siglos XVIII al XX. Documentos de Trabajo no. 109. Departamento de Investigaciones. Universidad de Belgrano, $18 \mathrm{pp}$

Faegri K, Iversen J (1992) Textbook of pollen analysis, 4the edn. Willey, Chichester, $328 \mathrm{pp}$

Fontana SL (2005) Holocene vegetation and palaeoenvironmental conditions on the temperate Atlantic coast of Argentina, as inferred from multi-proxy lacustrine records. J Paleolimnol 34:445-469

Fontana SL (2007) Radiocarbon chronologies of holocene lacustrine sediments from the southern coast of Buenos Aires province, Argentina. Radiocarbon 49:103-116

Fredlund G, Tieszen LT (1994) Modern phytolith assemblages from the North American Great Plains. J Biogeogr 21:321-335

Fredlund G, Tieszen L (1997) Calibrating grass phytolith assemblages in climatic terms: application to late Pleistocene assemblages from Kansas and Nebraska. Palaeogeogr Palaeoclimatol Palaeoecol 136:199-211

Frenguelli J (1941) Diatomeas del Río de la Plata. Rev Mus Nac La Plata Tomo 3:213-334

Frenguelli J (1945) Las diatomeas del Platense. Rev Mus Nac La Plata Tomo 3:77-221

García-Rodríguez F (2006) Inferring paleosalinity trends using the chrysophyte cyst to diatom ratio in coastal shallow temperate/subtropical lagoons influenced by sea level changes. J Paleolimnol 36:165-173

Garcia-Rodriguez F, Stutz S, Inda H, del Puerto L, Bracco R, Panario D (2010) Holocene paleobotanical changes in relation to the sea level variation and paleolimnological conditions of Negra Lagoon, SE Uruguay. Hydrobiologia 646:5-20

García-Rodríguez F, Sprechmann P, Metzeltin D, Scafati L, Melendi D, Volkheimer W, Mazzeo N, Hiller A, von Tümpling W Jr, Scasso F (2004) Holocene trophic state changes in relation to sea level variation in Lake Blanca, SE Uruguay. J Paleolimnol 31:99-115

Grimm EC (1987) CONISS: a Fortran 77 program for stratigraphically constrained cluster analysis by the method of incremental sum of squares. Comput Geosci 13:13-35

Grimm EC (2004) Tilia software. Illinois State Museum, Research and Collection Center, Springfield

Hammer $\varnothing$, Harper DAT, Ryan PD (2008) PAST - palaeontological statistics, ver. $1.81,88$ pp. http://folk.uio.no/ohammer/ past

Hassan GS, Espinosa MA, Isla FI (2006) Modern diatom assemblages in surface sediments from estuarine systems in the southeastern Buenos Aires Province, Argentina. J Paleolimnol 35:39-53

Head MJ, Borel CM, Guerstein GR, Harland R (2003) The problematic aquatic palynomorph genus Cobricosphaeridium Harland and Sarjeant, 1970 emend. and new records from the Holocene of Argentina. J Paleontol 77: 1159-1181
Heiri O, Lotter AF, Lemcke G (2001) Loss on ignition as a method for estimating organic and carbonate content in sediments: reproducibility and comparability of results. J Paleolimnol 25:101-110

Iriondo M, Garcia N (1993) Climatic variations in the Argentina plain during the last 18,000 years. Palaeogeogr Palaeoclimatol Palaeoecol 101:209-282

Isla FI (1989) Holocene sea level fluctuation in the Southern Hemisphere. Quat Sci Rev 8:59-368

Karst TL, Smol JP (2000) Paleolimnological evidence of limnetic nutrient concentration equilibrium in a shallow, macrophyte-dominated lake. Aquat Sci 62:20-38

Mancini MV (1994) Recent pollen sedimentation in Los Padres pond, Buenos Aires Province, Argentina. J Paleolimnol 10:25-34

Mancini MV, Paez MM, Prieto AR, Stutz S, Tonello M, Vilanova I (2005) Mid-Holocene climatic variability reconstruction from pollen records $\left(32^{\circ}-52^{\circ} \mathrm{S}\right.$, Argentina). Quat Int 132:47-59

Markgraf V, D'Antoni HL (1978) Pollen flora of Argentina. Modern spore and pollen types of Pteridophyta, Gimnospermae and Angiospermae. The University of Arizona Press, Tucson, $201 \mathrm{pp}$

Martens K, Behen F (1994) A checklist of the recent nonmarine ostracods (Crustacea, Ostracoda) from the inland waters of South America and Adjacent Islands. Trav Scient Mus Nat Hist Luxembourg 22:1-84

McCormac FG, Hogg AG, Blackwell PG, Buck CE, Higham TFG, Reimer PJ (2004) SHCal04 Southern Hemisphere Calibration 0-1000 cal BP. Radiocarbon 46:1087-1092

Metzeltin D, Lange-Bertalot H, García-Rodríguez F (2005) Diatoms of Uruguay. In H. Lange-Bertalot (ed) Iconographia Diatomologica, vol 15. A.R.G. Gantner Verlag distributed by Koeltz Scientific Books, Königstein, $737 \mathrm{pp}$

Prado JL, Alberdi MT (1999) The mammalian record and climatic change over the last 30,000 years in the Pampean Region, Argentina. Quat Inter 57/58:165-174

Prieto AR (1996) Late quaternary vegetational and climatic changes in the Pampa grassland of Argentina. Quat Res 45:73-88

Prieto AR (2000) Vegetational history of the late glacialHolocene transition in the grassland of eastern Argentina. Palaeogeogr Palaeoclimatol Palaeoecol 157:167-188

Prieto AR, Blasi AM, De Francesco CG, Fernández C (2004) Environmental history since 11,000 year B.P. of the northeastern Pampas, Argentina from alluvial sequences of Luján River. Quat Res 62:146-161

Quattrocchio ME, Borromei AM, Deschamps CM, Grill SC, Zavala CA (2008) Landscape evolution and climate changes in the late Pleistocene-Holocene, southern Pampa (Argentina): evidence from palynology, mammals and sedimentology. Quat Int 181:123-138

Rovner I (1992) Darwin and design in phytolith systematics: morphometric methods for mitigating redundancy. In: Rapp G Jr, Mullholland H (eds) Phytoliths systematics. Plenum Press, New York, pp 253-276

Scheffer M (1998) Ecology of shallow lakes, 1st edn. Chapman and Hall, London

Scheffer M, Jeppesen EJ (2007) Regime shifts in shallow lakes. Ecosystems 10:1-3 
Stuiver M, Reimer PJ, Reimer RW (2005) Calib 5.0.1. http://calib.qub.ac.uk/calib/

Stutz S, Prieto AR, Isla FI (1999) Cambios de la vegetación durante el Holoceno en el SE bonaerense: análisis polínico del paleoestuario del arroyo La Ballenera. APA Pub Especial 6:65-69

Stutz S, Prieto AR, Isla FI (2002) Historia de la vegetación de la laguna Hinojales, sudeste de la provincia de Buenos Aires, Argentina. Ameghiniana 39:85-94

Stutz S, Prieto AR, Isla FI (2006) Holocene evolution of the Mar Chiquita coastal lagoon area, Argentina, indicated by pollen analysis. J Quat Sci 21:17-28

Tonello MS, Prieto AR (2010) Tendencias climáticas para los pastizales pampeanos durante el Pleistoceno tardío-Holoceno: Estimaciones cuantitativas basadas en secuencias polínicas fósiles partir de registros polínicos fósiles. Ameghiniana (in press)

Tonni EP, Cione AL, Figini AJ (1999) Predominance of arid climates indicated by mammals in the pampas of Argentina during the Late Pleistocene and Holocene. Palaeogeogr Palaeoclimatol Palaeoecol 147:257-281

Tricart JL (1973) Geomorfologìa de la Pampa deprimida. Base para los estudios edafológicos y agronómicos XII Colección Científica INTA, 202 pp

Twiss PC (1992) Predicted world distribution of $C_{3}$ and $C_{4}$ grass phytoliths. In: Rapp G Jr, Mullholland H (eds) Phytoliths systematics. Plenum Press, New York, pp 113-127

van Geel B, Odgaard BV, Ralska-Jasiewiczowa M (1996) Cyanobacteria as indicators of phosphate-eutrophication of lakes and pools in the past. PACT 50:399-415

Vervoorst F (1967) La vegetación de la República Argentina. VII Las comunidades vegetales de la depresión del Salado
(Provincia de Buenos Aires). INTA, Serie Fitogeográfica 7, Buenos Aires, $259 \mathrm{pp}$

Vilanova I, Prieto AR, Espinosa M (2006) Palaeoenvironmental evolution and sea-level fluctuations along the southeastern Pampa grasslands coast of Argentina during the Holocene. J Quat Sci 21:227-242

Villalba R, Masiokas M, Kitzberger T, Boninsegna J (2005) Biogeographical consequences of recent climate changes in the Southern Andes of Argentina. In: Huber U, Bugmann HKM, Reasoner MA (eds) Global change and mountain region: an overview of current knowledge. Series advances in global change research. Springer, New York, 23, $650 \mathrm{pp}$

Violante RA (1992) Ambientes sedimentarios asociados a un sistema de barrera litoral del Holoceno en la llanura costera al sur de Villa Gesell, Provincia de Buenos Aires. RAGA 47:201-214

Violante RA, Parker G, Cavallotto JL (2001) Evolución de las llanuras costeras del este bonaerense entre la bahía Samborombón y la laguna Mar Chiquita durante el Holoceno. RAGA 56:51-66

Whatley R, Moguilevsky A, Toy N, Chadwick J, Ramos MIF (1997) Ostracoda from the south west Atlantic. Part II. The littoral fauna from between Tierra del Fuego and the Río de La Plata. Rev Españ Micropaleont 29:5-83

Zárate M, Kemp RA, Espinosa M, Ferrero L (2000) Pedosedimentary and palaeoenvironmental significance of a Holocene alluvial sequence in the southern Pampas, Argentina. Holocene 10:481-488 